\section{Pacific Northwest}

National Laboratory

Operated by Battelle for the

U.S. Department of Energy

\title{
High-Level Waste Tank Lay-Up Assessment Year-End Progress Report
}

\author{
M. Elmore \\ C. Henderson*
}

September 26, 2001

* Jacobs Engineering Group, Inc.

Prepared for the U.S. Department of Energy under Contract DE-AC06-76RL01830 


\title{
DISCLAIMER
}

This report was prepared as an account of work sponsored by an agency of the United States Government. Neither the United States Government nor any agency thereof, nor Battelle Memorial Institute, nor any of their employees, makes any warranty, express or implied, or assumes any legal liability or responsibility for the accuracy, completeness, or usefulness of any information, apparatus, product, or process disclosed, or represents that its use would not infringe privately owned rights. Reference herein to any specific commercial product, process, or service by trade name, trademark, manufacturer, or otherwise does not necessarily constitute or imply its endorsement, recommendation, or favoring by the United States Government or any agency thereof, or Battelle Memorial Institute. The views and opinions of authors expressed herein do not necessarily state or reflect those of the United States Government or any agency thereof.

\author{
PACIFIC NORTHWEST NATIONAL LABORATORY \\ operated by \\ BATTELLE \\ for the \\ UNITED STATES DEPARTMENT OF ENERGY \\ under Contract DE-AC06-76RL01830
}

Printed in the United States of America

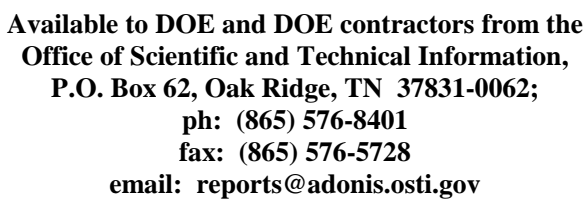

Available to the public from the National Technical Information Service, U.S. Department of Commerce, 5285 Port Royal Rd., Springfield, VA 22161 ph: (800) 553-6847 fax: $(703) 605-6900$

email: orders@ntis.fedworld.gov

online ordering: http://www.ntis.gov/ordering.htm 
PNNL-13899

\section{High-Level Waste Tank Lay-Up Assessment - Year-End Progress Report}

September 26, 2001

Prepared for

Tanks Focus Area and

the U.S. Department of Energy

under Contract DE-AC06-76RL01830

Jacobs Engineering Group, Inc., and

Pacific Northwest National Laboratory

Richland, Washington 99352 


\section{CONTENTS}

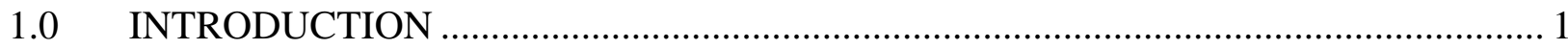

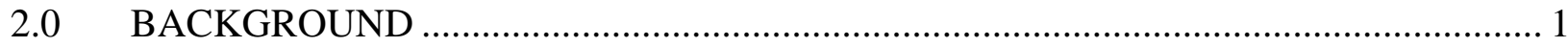

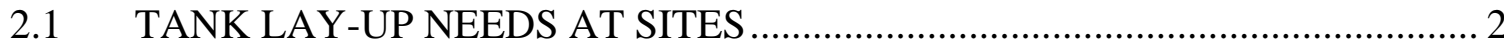

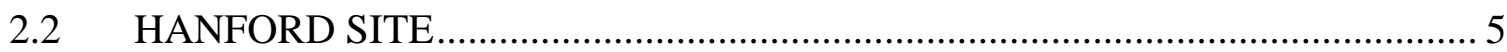

2.3 SAVANNAH RIVER SITE.............................................................................. 5

2.4 IDAHO NATIONAL ENGINEERING AND ENVIRONMENTAL

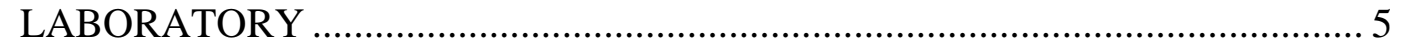

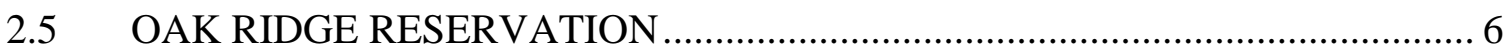

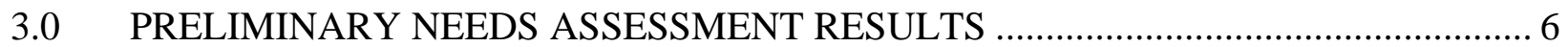

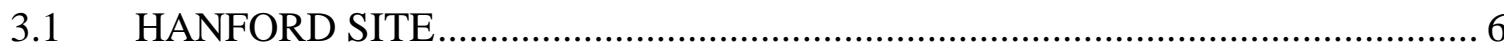

3.2 SAVANNAH RIVER SITE.......................................................................... 9

3.3 IDAHO NATIONAL ENGINEERING AND ENVIRONMENTAL

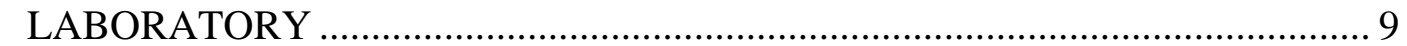

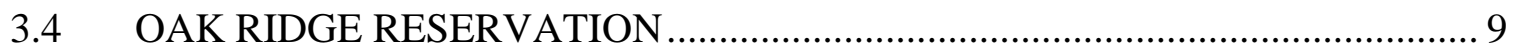

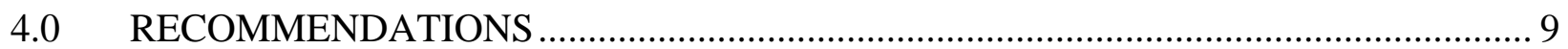

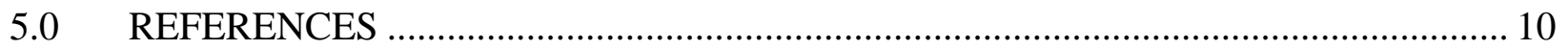

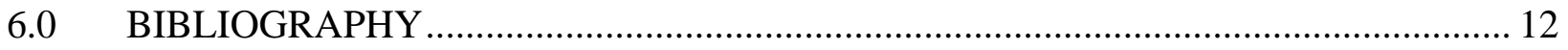

\section{TABLES}

1. Comparison of Site High-Level Waste Tank Programs ......................................................... 3

2. Site High-Level Waste Lay-Up Requirements and Considerations ...................................... 7 


\section{LIST OF TERMS}

DOE U.S. Department of Energy

EIS environmental impact statement

FY fiscal year

HLW high-level waste

INEEL Idaho National Engineering and Environmental Laboratory

ORR Oak Ridge Reservation

SRS Savannah River Site

WVDP West Valley Demonstration Project 


\subsection{INTRODUCTION}

This report documents the preliminary needs assessment of high-level waste (HLW) tank lay-up requirements and considerations for the Hanford Site, Idaho National Engineering and Environmental Laboratory (INEEL), Savannah River Site (SRS), and Oak Ridge Reservation (ORR). This assessment includes the development of a high-level requirements and considerations list that evolved from work done for the West Valley Demonstration Project (WVDP) earlier in fiscal year (FY) 2001, and is based on individual site conditions and tank retrieval/tank closure schedules. Because schedules are continually subject to change, this assessment is considered preliminary and needs review and validation by the individual sites. The lay-up decision methodology developed for WVDP was based on standard systems engineering principles, and provided a structured framework for producing an effective, technically-defensible lay-up strategy.

On September 6, 2001, the results from the WVDP work were briefed to the Tank Focus Area Strategic Initiatives Review Board along with recommended follow-on work in FY 2002. Based on the verbal feedback during that meeting, there appear to be two potential paths for follow-on work. The first would be developing a tank lay-up informational database. This would include compiling a bibliography of documents from across the U.S. Department of Energy (DOE) complex concerning subjects of potential interest to lay-up, such as residual waste characterization and stabilization, tank integrity evaluation, surface and subsurface barrier installation and evaluation, high-performance cleanout methods and leak detection technologies, and techniques to reduce tank surveillance, monitoring, and maintenance. The second path would be the development of detailed lay-up requirements and considerations for one tank at one site. This would include developing cost estimates for continued operation of the tank under existing site requirements and the costs for lay-up of that one tank. This evaluation would provide a programmatic baseline for tank lay-up which could be of value to all sites. These two paths are not necessarily mutually exclusive. This task is currently awaiting the recommendations of the Review Board.

Background information is provided on each of the sites, including a comparison of the tank management programs. Finally, recommendations for follow-on work are provided.

\subsection{BACKGROUND}

HLW tanks were constructed and operated at a number of DOE sites to store waste that was mainly generated from the reprocessing of spent nuclear fuel. The initial step in remediating tank waste involves the retrieval and treatment of the tank waste for disposal. The second step involves dispositioning the tank facilities. Plans have been developed and are in various stages of implementation across the complex for the retrieval and treatment of the waste contained in the tanks and the tanks. Plans are less defined for how the tanks will be managed following retrieval and how they will be closed.

Each HLW tank in the DOE complex must transition from completion of its operational life to final closure, and depending on the uncertainty in the closure requirements or the uncertainty with closure decision making, the time this may take varies greatly. Technical, programmatic, and/or regulatory issues may make this tank transition management period last for years or even decades. Prudent tank closure planning accomplishes the following: 
- Recognizes the potentially extended closure period

- Identifies objectives, requirements, and considerations

- Considers interim, pre-closure actions to place the tank and any residual contents into a safe, stable, and minimum maintenance condition without compromising final closure options.

The interim condition is referred to as tank lay-up. Tank lay-up recognizes that this period of time is different than normal tank operations, and this difference warrants evaluation of the requirements for configuring, operating, and maintaining the tanks during the transition from waste storage to closure. Tank lay-up is the bridge between the waste storage phase and closure phase in the life cycle of a tank.

The complexity and extent of tank lay-up actions will likely vary depending on the following:

- Lay-up period

- Tank's operating history and physical condition

- Current understanding of closure requirements

- Perceived risks of any residual waste.

One of the first actions in managing tank transition is the development of requirements and considerations for tank lay-up. Sites whose current schedules reflect relatively short transition periods may foresee few or no lay-up needs. Sites with relatively long transition periods may execute extensive lay-up plans, to minimize surveillance/monitoring costs and show progress toward closure.

\section{$2.1 \quad$ TANK LAY-UP NEEDS AT SITES}

Tank lay-up needs are a function of a number of different variables. The need for, and potential benefits from, tank lay-up depend on the number and physical condition of the tanks, the potential lay up period, the uncertainty in tank closure requirements, the risks associated with the waste heel, and the regulatory environment.

The intent of the lay-up period is to reevaluate the requirements and consider what is known about the tank, tank farm, and future tank closure criteria. The decision process developed for WVDP provides a means to weight the requirements and considerations based on individual site conditions and considerations.

Table 1 is a comparison of the tank programs at the various sites. WVDP is included for completeness. An evaluation of that site's tank lay-up requirements and considerations has been previously reported (Henderson, 2001a, b, c, and d).

The Hanford Site and SRS have $80 \%$ of the total HLW tanks to be closed, more than $95 \%$ of the HLW requiring retrieval and disposal, and all of the known and assumed leaking tanks. Because of the current uncertainties in these cleanup and closure programs, they may also have the greatest potential need for tank lay-up planning. 
Table 1. Comparison of Site High-Level Waste Tank Programs (2 Sheets)

\begin{tabular}{|c|c|c|c|c|c|}
\hline & WVDP & Hanford Site & SRS & INEEL & ORR \\
\hline $\begin{array}{l}\text { Number of tanks/areas to } \\
\text { close }\end{array}$ & $4 / 1$ area & $177 / 18$ tank farms & $51 / 2$ tank farms & $11^{\mathrm{a}} / 1$ tank farm & $40 / 5$ tank farms \\
\hline Tank types & 2 & 2 & 4 & 2 & 6 \\
\hline Tank sizes, $10^{3}$ gal & $15-750$ & $55-1,160$ & $750-1,300$ & 318 & $1.5-170$ \\
\hline Tank ages, years & 35 & $15-58$ & $20-50$ & $37-50$ & $3-58$ \\
\hline Tank conditions & No leakers & $\begin{array}{l}67 \text { confirmed and } \\
\text { assumed leakers }\end{array}$ & 11 leakers & No leakers & No leakers \\
\hline Waste types & Alkaline & $\begin{array}{l}\text { Viscous, alkaline } \\
\text { liquid, sludge, salt } \\
\text { cake }\end{array}$ & $\begin{array}{l}\text { Viscous, alkaline liquid, } \\
\text { sludge, salt cake }\end{array}$ & $\begin{array}{l}\text { Acidic, liquid sodium } \\
\text { waste, sludges; calcined } \\
\text { powder }\end{array}$ & Liquids, sludges \\
\hline Waste volumes, $10^{6} \mathrm{gal}$ & 0.6 & 54 & 33 & 1.4 & 0.4 \\
\hline $\begin{array}{l}\text { Waste radionuclides, } \\
10^{6} \mathrm{Ci}\end{array}$ & 0.03 & 200 & 470 & 0.52 & 0.047 \\
\hline Retrieval schedule & $\begin{array}{l}\text { Tank heels cleaned out in } \\
2001 \text { to Class C limits }\end{array}$ & $\begin{array}{l}\text { SSTs complete by } \\
2018^{\mathrm{b}} \text { and DSTs by } \\
2028^{\mathrm{b}}\end{array}$ & $\begin{array}{l}2019 \text { for Type I, II, and } \\
\text { IV; } 2024 \text { for Type III }\end{array}$ & $\begin{array}{l}\text { HLW complete } 1998 \text {; } \\
\text { remaining liquid waste } \\
\text { by } 2012\end{array}$ & $\begin{array}{l}90 \% \text { of inactive tanks } \\
\text { complete. Remainder } \\
\text { as mission is completed }\end{array}$ \\
\hline Closure schedule & $\begin{array}{l}\text { Not yet finalized; closure } \\
\text { expected to take up to } 20 \\
\text { years }\end{array}$ & $\begin{array}{l}\text { SSTs by } 2024^{\mathrm{b}} \text { and } \\
\text { DSTs by } 2032^{\mathrm{b}}\end{array}$ & $\begin{array}{l}2022 \text { for Type I, II, and } \\
\text { IV; Type III by } 2030\end{array}$ & $\begin{array}{l}\text { In six phases from } 2005 \\
\text { to } 2016\end{array}$ & $\begin{array}{l}24 \text { tanks without } \\
\text { secondary containment } \\
\text { by } 2022 \text {; others as } \\
\text { storage mission is } \\
\text { completed }\end{array}$ \\
\hline $\begin{array}{l}\text { Tank maximum ages in } \\
\text { years at closure }\end{array}$ & More than 50 & More than 75 & More than 75 & More than 60 & More than 70 \\
\hline $\begin{array}{l}\text { Approved final closure } \\
\text { requirements }\end{array}$ & No & No & $\begin{array}{l}\text { Some top-level } \\
\text { developed }\end{array}$ & $\begin{array}{l}\text { Some top-level } \\
\text { developed }\end{array}$ & No \\
\hline
\end{tabular}


Table 1. Comparison of Site High-Level Waste Tank Programs (2 Sheets)

\begin{tabular}{|l|l|l|l|l|}
\cline { 2 - 5 } \multicolumn{1}{c|}{} & \multicolumn{1}{c|}{ WVDP } & \multicolumn{1}{c|}{ Hanford Site } & \multicolumn{1}{c|}{ INEEL } & \multicolumn{1}{c|}{ ORR } \\
\hline $\begin{array}{l}\text { Closure regulatory } \\
\text { drivers }\end{array}$ & $\begin{array}{l}\text { DOE/EIS-0226-D; } \\
\text { NYSERDA 1980; WVDP } \\
\text { Acts of 1980 \& 1991 }\end{array}$ & $\begin{array}{l}\text { DOE/EIS-0189; } \\
\text { DOE/EIS-0222F; } \\
\text { Ecology et al. 1989; } \\
\text { MOU 1996 }\end{array}$ & $\begin{array}{l}\text { DOE/EIS-0217; } \\
\text { DOE/EIS-0303D; Site } \\
\text { Treatment Plan; } \\
\text { Supplemental EIS; } \\
\text { Wastewater Closure } \\
\text { Plan; WSRC-OS-94-42 }\end{array}$ & $\begin{array}{l}\text { DOE/EIS-0287D; } \\
\text { DOE-ID 1991; } \\
\text { Settlement Agreement }\end{array}$ \\
\hline $\begin{array}{l}\text { Site and tank specific } \\
\text { considerations and } \\
\text { uncertainties }\end{array}$ & $\begin{array}{l}\text { Corrosion, in-tank } \\
\text { hardware; water in vaults }\end{array}$ & $\begin{array}{l}\text { In-tank hardware; } \\
\text { arid climate; well } \\
\text { above water table; } \\
\text { contaminated vadose } \\
\text { zone/groundwater }\end{array}$ & $\begin{array}{l}\text { In-tank hardware; some } \\
\text { tanks in water table; } 2 \\
\text { tanks interim closed in } \\
\text { 1997 }\end{array}$ & $\begin{array}{l}\text { Tanks are stainless } \\
\text { steel; in-tank hardware; } \\
\text { seismic; no secondary } \\
\text { containment }\end{array}$ \\
\hline
\end{tabular}

${ }^{a}$ Plus an additional 7 calcine bin sets, containing 3.8 million L (24 million Ci) of calcined HLW, and four 30,000 gal stainless tanks in the tank farm facility.

${ }^{\mathrm{b}}$ Currently reevaluating to extend dates.

DST $=$ double-shell tank.

EIS = environmental impact statement.

FFCA $=$ Federal Facility Compliance Agreement.

HLW = high-level waste.

INEEL = Idaho National Engineering and Environmental Laboratory.

MOU $=$ memorandum of understanding.

ORR = Oak Ridge Reservation.

SRS = Savannah River Site.

SST $=$ single-shell tank .

WVDP $=$ West Valley Demonstration Project. 


\subsection{HANFORD SITE}

Nearly two-thirds of all DOE HLW tanks and tank waste, and $85 \%$ of all confirmed and assumed leaking tanks are located at the Hanford Site. Many of the tanks are inactive and essentially empty. Waste retrieval projects are planned that would empty additional tanks over the next few years. An environmental impact statement (EIS) for retrieval and treatment of the tank waste has been issued, but tank closure requirements have not been finalized and closure decisions are not expected in the near term. Some of the older single-shell tanks, with single carbon steel liners, are nearly 60 years old. Waste retrieval and tank closure schedules are likely to be extended even further into the future because of the shortage of storage space in the newer, double-shell tanks, and because of recent delays in the tank waste disposal program. In addition, there are a myriad of regulatory, programmatic, and technical uncertainties and issues that will require resolution prior to tank closure. Agreement on future land use scenarios for tank farm closure evaluations are in progress, but work on a tank closure EIS has not yet begun.

The baseline strategy is to close the tanks and farms in place, but how much waste has to be removed and what actions need to be taken for past leaks and potential leaks during waste retrieval have not been established.

\subsection{SAVANNAH RIVER SITE}

More than two-thirds of the total curies to be retrieved and disposed in the DOE complex are contained in the HLW at the SRS. At least 10 of the tanks have leaked and/or have cracks in the tank liners. Two tanks have been interim closed, but a new EIS is required before any further tanks can be closed. Many of the older tanks will be nearly 70 years old before planned closure. Even the newest tanks are expected to be 60 years of age before closure. One tank was cleaned out 20 years ago, but is not yet closed. Several more tanks are expected to be cleaned out in the near future, but closure dates are uncertain. And, like at the Hanford Site, there are regulatory, programmatic, and technical issues surrounding final closure that will be addressed in the new EIS.

The baseline strategy is to close the tanks in place after stabilizing the tanks and any residual waste with grout.

\subsection{IDAHO NATIONAL ENGINEERING AND ENVIRONMENTAL LABORATORY}

Liquid HLW was removed from the INEEL tanks and calcined in 1998. Contaminated, sodium-bearing, liquid waste remains in the tanks at INEEL. The waste is in acidic form (little sludge) in 11 stainless steel tanks, awaiting a final disposal process. While the proposed path for disposal of the HLW is well defined, tank closure requirements and approvals are not yet finalized. Tank closure plans do address 'operational or interim closure' as a DOE/Resource Conservation and Recovery Act of 1976 action on the path to final closure.

The baseline strategy is to close the tanks and farm in place after filling the tanks and ancillary piping with grout. 


\subsection{OAK RIDGE RESERVATION}

The waste in the tanks at ORR, though physically, chemically, and radiologically similar to HLW at other sites, is not classified as HLW. Consolidation of all waste into the higher integrity tanks is well underway, and a Record of Decision is expected shortly that will allow interim closure of tanks by filling with a removable grout. All tanks without secondary containment are expected to be closed in the next 20 years and the remaining tanks within 30 years.

The baseline closure strategy is to clean out all tanks to meet waste acceptance criteria, then fill the tanks with grout.

\subsection{PRELIMINARY NEEDS ASSESSMENT RESULTS}

One of the initial products from FY 2001 work in support of WVDP was a list of the tank lay-up requirements and considerations. This list was evolved for each of the other tank sites, considering site-specific factors. The results are shown in Table 2.

There appear to be many Hanford Site and SRS HLW tanks that have potential lay-up periods in excess of 20 years, suggesting a higher potential need for lay-up planning at these two sites. Conversely, execution of the INEEL and ORR tank retrieval and closure programs appears more near-term and better defined, although tank lay-up considerations apply to these sites as well. One measure of the complexity of tank lay-up and closure is the number of significant issues that must be addressed. For this reason, potential site lay-up issues have been included in the table.

There is not a straight-forward regulatory path for tank lay-up. Lay-up actions may require regulatory approval, although regulatory requirements during lay-up are expected to be less restrictive than for normal operation. Examples of baseline documentation potentially impacted by lay-up considerations include operating specifications, technical safety requirements, safety analyses reports, and operating procedures. Depending on the regulatory framework, lay-up options may vary significantly between sites, and even between tanks at the same site. A sitespecific and tank-specific evaluation process should be developed for the tanks as they reach the end of their operational life. Appropriate DOE orders, Resource Conservation and Recovery Act of 1976 and Comprehensive Environmental Response, Compensation, and Liability Act of 1980 regulations, and federal facility agreements should be evaluated against the known status of the tank, then lay-up (or closure) decisions made. This evaluation should include potential renegotiation, modification, or waiver of requirements in these documents based on the tank's proposed lay-up condition. The lay-up plan must also consider the individual tank(s) within the context of the closure plans for the tank's environment (e.g., tank farm and ancillary equipment, existing and projected waste leaks, soil and groundwater properties, site meteorology, seismology).

\subsection{HANFORD SITE}

While the path for near-term retrieving and processing tank wastes is relatively well defined, final closure of the tanks and tank sites is complicated by a myriad of challenging issues. This means that, over the next few years, an increasing number of very old, single-shell tanks will be cleaned out and will likely have to wait for a number of years before final closure. These tanks will be prime candidates for lay-up. 


\begin{tabular}{|c|c|c|c|c|c|c|}
\hline \multicolumn{2}{|c|}{$\begin{array}{c}\text { Requirements, } \\
\text { Considerations, and } \\
\text { Potential Issues }\end{array}$} & WVDP & Hanford Site & SRS & INEEL & ORR \\
\hline \multirow{3}{*}{ : } & $\begin{array}{l}\text { Ensure acceptable } \\
\text { risks to workers and } \\
\text { public }\end{array}$ & $\begin{array}{l}\text { Establish safe operating } \\
\text { envelope during lay-up. } \\
\text { Maintain tank integrity. } \\
\text { Prevent leaks to } \\
\text { groundwater. }\end{array}$ & $\begin{array}{l}\text { Minimize leaks to } \\
\text { ground, air emissions. } \\
\text { Maintain tank integrity. } \\
\text { Minimize liquid ingress } \\
\text { to tank. }\end{array}$ & $\begin{array}{l}\text { Minimize leaks to soil, } \\
\text { groundwater, air } \\
\text { emissions. Maintain tank } \\
\text { integrity. Minimize } \\
\text { liquid ingress to tank. }\end{array}$ & $\begin{array}{l}\text { Treat tank and vault } \\
\text { exhausts as necessary. }\end{array}$ & $\begin{array}{l}\text { Store old and currently } \\
\text { generated waste in } \\
\text { highest integrity tanks. }\end{array}$ \\
\hline & $\begin{array}{l}\text { Comply with } \\
\text { regulations, permits, } \\
\text { and agreements }\end{array}$ & $\begin{array}{l}\text { Table } 1 \text { regulatory } \\
\text { drivers, plus DOE letter } \\
\text { with Class C limits on } \\
\text { tank cleanout. }\end{array}$ & $\begin{array}{l}\text { Table } 1 \text { regulatory } \\
\text { drivers, plus } \\
\text { authorization basis, } \\
\text { closure EIS, incidental } \\
\text { waste determination. }\end{array}$ & $\begin{array}{l}\text { Table } 1 \text { regulatory } \\
\text { drivers, plus new tank } \\
\text { closure EIS, incidental } \\
\text { waste determination, } \\
\text { impact of NRDC lawsuit } \\
\text { (DOE O 435.1), land use } \\
\text { implementation. }\end{array}$ & $\begin{array}{l}\text { Table } 1 \text { regulatory } \\
\text { drivers. }\end{array}$ & $\begin{array}{l}\text { Table } 1 \text { regulatory } \\
\text { drivers. }\end{array}$ \\
\hline & $\begin{array}{l}\text { Preserve future tank } \\
\text { closure options }\end{array}$ & $\begin{array}{l}\text { Preserve future options } \\
\text { for tank decontamination } \\
\text { and closure. }\end{array}$ & $\begin{array}{l}\text { Consider the potential for } \\
\text { secondary waste retrieval, } \\
\text { remediation of } \\
\text { contaminated soils, and } \\
\text { remediation of ancillary } \\
\text { equipment. }\end{array}$ & $\begin{array}{l}\text { No tank closures until } \\
\text { approval of new EIS. }\end{array}$ & $\begin{array}{l}\text { Tank closure criteria } \\
\text { awaiting DOE/RCRA } \\
\text { documentation. }\end{array}$ & $\begin{array}{l}\text { Tank closures awaiting } \\
\text { ROD and resolution of } \\
\text { heel technical issues. }\end{array}$ \\
\hline \multirow{4}{*}{ 苞 } & $\begin{array}{l}\text { Control life-cycle } \\
\text { costs }\end{array}$ & $\begin{array}{l}\text { Control capital and } \\
\text { operating costs. Reduce } \\
\text { tank surveillance and } \\
\text { monitoring. }\end{array}$ & $\begin{array}{l}\text { Reduce surveillance, } \\
\text { monitoring, and } \\
\text { maintenance } \\
\text { requirements during lay- } \\
\text { up period. }\end{array}$ & $\begin{array}{l}\text { Reduce surveillance, } \\
\text { monitoring, and } \\
\text { maintenance } \\
\text { requirements during lay- } \\
\text { up period. }\end{array}$ & $\begin{array}{l}\text { Utilize existing systems } \\
\text { to greatest extent } \\
\text { possible. Leave } \\
\text { equipment in tanks when } \\
\text { possible. }\end{array}$ & $\begin{array}{l}\text { Close inactive tanks as } \\
\text { soon as possible after } \\
\text { waste acceptance criteria } \\
\text { is satisfied. }\end{array}$ \\
\hline & $\begin{array}{l}\text { Gain stakeholder } \\
\text { acceptance/ } \\
\text { consensus }\end{array}$ & $\begin{array}{l}\text { Involve key decision } \\
\text { makers and stakeholders } \\
\text { in planning/approval } \\
\text { process. }\end{array}$ & $\begin{array}{l}\text { Involve key decision } \\
\text { makers and stakeholders } \\
\text { in planning/approval } \\
\text { process. }\end{array}$ & $\begin{array}{l}\text { Involve key decision } \\
\text { makers and stakeholders } \\
\text { in planning/approval } \\
\text { process. }\end{array}$ & $\begin{array}{l}\text { Involve key decision } \\
\text { makers and stakeholders } \\
\text { in planning/approval } \\
\text { process. }\end{array}$ & $\begin{array}{l}\text { Involve key decision } \\
\text { makers and stakeholders } \\
\text { in planning/approval } \\
\text { process. }\end{array}$ \\
\hline & $\begin{array}{l}\text { Minimize secondary } \\
\text { wastes }\end{array}$ & $\begin{array}{l}\text { Ensure secondary wastes } \\
\text { can be readily disposed. }\end{array}$ & $\begin{array}{l}\text { Use existing waste for } \\
\text { retrieval. Dispose } \\
\text { secondary wastes. }\end{array}$ & $\begin{array}{l}\text { Ensure secondary wastes } \\
\text { can be readily disposed. }\end{array}$ & $\begin{array}{l}\text { Ensure secondary wastes } \\
\text { can be readily disposed. }\end{array}$ & $\begin{array}{l}\text { Ensure secondary wastes } \\
\text { can be readily disposed. }\end{array}$ \\
\hline & $\begin{array}{l}\text { Use proven and } \\
\text { accepted } \\
\text { technologies }\end{array}$ & $\begin{array}{l}\text { Include demonstrated } \\
\text { construction methods. }\end{array}$ & $\begin{array}{l}\text { Full-scale demonstration } \\
\text { of retrieval technologies. }\end{array}$ & $\begin{array}{l}\text { Modify techniques used } \\
\text { to interim close two } \\
\text { tanks. }\end{array}$ & $\begin{array}{l}\text { Washball system to be } \\
\text { used for cleanout. }\end{array}$ & $\begin{array}{l}\text { Modify solids removal } \\
\text { methods from other sites. }\end{array}$ \\
\hline
\end{tabular}


Table 2. Site High-Level Waste Lay-Up Requirements and Considerations (2 Sheets)

\begin{tabular}{|c|c|c|c|c|c|c|}
\hline \multicolumn{2}{|c|}{$\begin{array}{c}\text { Requirements, } \\
\text { Considerations, and } \\
\text { Potential Issues }\end{array}$} & WVDP & Hanford Site & SRS & INEEL & ORR \\
\hline 悉 & Specific to site & $\begin{array}{l}\text { Ability to keep tank } \\
\text { external surfaces dry. } \\
\text { Ability to control oxygen } \\
\text { (corrosion) in tanks. } \\
\text { Effectiveness of } \\
\text { groundwater barriers. }\end{array}$ & $\begin{array}{l}\text { Dome loading, liner } \\
\text { integrity analysis, leak } \\
\text { detection; waste heel } \\
\text { characterization/ } \\
\text { inventory and } \\
\text { classification; tank } \\
\text { isolation, barriers; tank } \\
\text { atmosphere control; } \\
\text { retrieval performance; } \\
\text { groundwater/vadose zone } \\
\text { modeling, assessment; } \\
\text { future land use. }\end{array}$ & $\begin{array}{l}\text { Liner cracks; waste in } \\
\text { annuli; waste in } \\
\text { groundwater; ingress of } \\
\text { groundwater into tanks. }\end{array}$ & $\begin{array}{l}\text { Ability to demonstrate } \\
\text { clean closure of tanks; in } \\
\text { tank equipment; } \\
\text { contaminated soil; source } \\
\text { terms, groundwater } \\
\text { modeling; future land use } \\
\text { requirements. }\end{array}$ & $\begin{array}{l}\text { Groundwater leaks into } \\
\text { tanks; resin beads in the } \\
\text { bottoms of some tanks. }\end{array}$ \\
\hline
\end{tabular}

DOE $=$ U.S. Department of Energy.

EIS = environmental impact statement.

INEEL = Idaho National Engineering and Environmental Laboratory.

NRDC $=$ National Resources Defense Council

ORR $=$ Oak Ridge Reservation .

RCRA = Resource Conservation and Recovery Act of 1976

ROD $=$ Record of Decision.

SRS = Savannah River Site.

WVDP $=$ West Valley Demonstration Project. 


\subsection{SAVANNAH RIVER SITE}

While the SRS has demonstrated interim closure on two tanks, future progress is clouded by the requirement for a new EIS before any further closure actions can be taken. These closure uncertainties, fueled by a relatively aggressive waste retrieval schedule, provide a good environment for considering lay-up.

\subsection{IDAHO NATIONAL ENGINEERING AND ENVIRONMENTAL LABORATORY}

Because of the relatively small amount of HLW remaining to be retrieved from a few nonleaking, stainless steel tanks, there is currently a diminished need for extensive lay-up planning at the site. However, because current closure plans are still not approved, INEEL could benefit from involvement in the lay-up planning process and from the results of a detailed evaluation of one tank at another site.

\subsection{OAK RIDGE RESERVATION}

More than half of the ORR tanks are already grouted, awaiting a Record of Decision that would allow them to be closed in-place without further action. Because of this and the fact that closure actions are not complicated by HLW considerations, the need for lay-up planning appears low. However, judicious and complete closure planning may require consideration of possible delays in the closure program, and ORR could benefit from involvement in the lay-up planning process.

\subsection{RECOMMENDATIONS}

The dialogue on tank lay-up needs to be expanded to the sites that are potentially most affected. This preliminary evaluation report is one vehicle for stimulating that dialogue and could be reviewed informally with the sites. This should include a review of the list of requirements and considerations for comprehensiveness. In parallel, this tank lay-up effort should be coordinated with the next Tank Closure Workshop, which may be scheduled sometime later in calendar year 2001. Interest and support at this workshop could greatly enhance the likelihood of involving subject matter experts at the key sites later on.

Selection of a path forward for this initiative will be made once the Tank Focus Area Strategic Initiative Review Board issues its recommendations. If it is decided to pursue a detailed lay-up evaluation for one tank, technical, programmatic, and regulatory issues should be developed as well. Candidates include tanks AX-104 and C-106 at the Hanford Site and tank 16 at the SRS. The success of this process will be highly dependent on the degree of interest and the commitment of subject matter experts at the selected site.

The tank lay-up evaluation process would include the following steps:

- Identify tank lay-up requirements and considerations

- Identify potential lay-up strategies

- Identify potential lay-up technologies

- Identify potential uncertainties and issues

- Configure lay-up alternatives for evaluation

- Evaluate lay-up alternatives using a weighted decision matrix. 
This process will lead to a technically-defensible lay-up strategy for that one tank. The results of this evaluation can be applied generically by the other sites to tailor lay-up plans on an individual tank basis. Tank lay-up options resulting from this process would include the following:

- Continued operation of the tank in the same manner as before the waste was retrieved

- Wet lay-up of the tank with the addition of corrosion inhibitors

- Dry lay-up (drying the residual waste and tank atmosphere)

- Dry lay-up with the addition of a stabilizing material to the residual waste.

\subsection{REFERENCES}

Comprehensive Environmental Response, Compensation, and Liability Act of 1980, Public Law 96-150, 94 Stat. 2767, Title 26, 42 USC 9601 et seq.

DOE/EIS-0189, 1996, Tank Waste Remediation System, Hanford Site, Richland, Washington, Final Environmental Impact Statement, U.S. Department of Energy, Washington, D.C.

DOE/EIS-0217, 1995, Savannah River Site, Waste Management, Final Environmental Impact Statement, 2 volumes, U.S. Department of Energy Savannah River Operations Office, Aiken, South Carolina.

DOE/EIS-0222F, 1999, Final Hanford Comprehensive Land Use Plan Environmental Impact Statement, U.S. Department of Energy, Richland Operations Office, Richland, Washington.

DOE/EIS-0226-D, 1996, Draft Environmental Impact Statement for Completion of the West Valley Demonstration Project and Closure of Long-Term Management of Facilities at the Western New York Nuclear Service Center, U.S. Department of Energy, New York State Energy Research and Development Authority, New York.

DOE/EIS-0287D, 1999, Idaho High-Level Waste and Facilities Disposition Draft Environmental Impact Statement, U.S. Department of Energy, Washington, D.C.

DOE/EIS-0303D, 2000, High Level Waste Tank Closure, Draft Environmental Impact Statement, U.S. Department of Energy, Savannah River Operations Office, Aiken, South Carolina.

DOE-ID, 1991, Federal Facility Agreement and Consent Order and Action Plan, U.S. Department of Energy, Idaho Field Office, U.S. Environmental Protection Agency, Region 10, Idaho Department of Health and Welfare, Idaho Falls, Idaho.

DOE O 435.1, 1997, Radioactive Waste Management, U.S. Department of Energy, Washington, D.C.

DOE/OR-1014, 1992, Federal Facility Agreement for the Oak Ridge Reservation, U.S. Department of Energy Oak Ridge Operations Office, Environmental Protection Agency, and the Tennessee Department of Environmental and Conservation, U.S. Department of Energy, Oak Ridge Operations Office, Oak Ridge, Tennessee. 
Ecology, EPA, and DOE, 1989, Hanford Federal Facilities Agreement and Consent Order, as amended, Washington State Department of Ecology, U.S. Environmental Protection Agency, U.S. Department of Energy, Olympia, Washington.

Henderson, C., 2001a, "Contract No. TTPRL30WT21A, Milestone No. A.1-1, "Submittal of Functions and Requirements for WVDP Tank Lay-up" (Letter Report \#1 to Michael Terry, Safety Technology Integration Manager, Tanks Focus Area, PNNL, March 15), Jacobs Engineering Group Inc., Richland, Washington.

Henderson, C., 2001b, “Contract No. TTPRL30WT21A, Milestone No. A.2-1, "Issue Tank Lay-Up Strategies Report for WVDP” (Letter Report \#2 to Michael Terry, safety Technology Integration Manager, Tanks Focus Area, PNNL, April 16), Jacobs Engineering Group Inc., Richland, Washington.

Henderson, C., 2001c, “Contract No. TTPRL30WT21A, Milestone No. A.3-1, "Issue Decision Plan for WVDP Tank Lay-Up” (Letter Report \#3 to Michael Terry, Safety Technology Integration Manager, Tanks Focus Area, PNNL, May 25), Jacobs Engineering Group Inc., Richland, Washington.

Henderson, C., 2001d, “Contract No. TTPRL30WT21A, Milestone No. A.4-1, "Issue Tank Lay-Up Strategies For West Valley Demonstration Project Final Report” (Letter Report to Monte Elmore, Principal Investigator, PNNL, June 29), Jacobs Engineering Group Inc., Richland, Washington.

MOU, 1996, Memorandum of Understanding: Required Percent of Waste Retrieval, U.S. Department of Energy and Washington State Department of Ecology, Richland, Washington.

NYSERDA, 1980, Cooperative Agreement Between the U.S. Department of Energy and the New York State Energy Research and Development Authority, New York State Energy Research and Development Authority, Albany, New York.

Resource Conservation and Recovery Act of 1976, Public Law 94-580, 90 Stat. 2795, 42 USC 901 et seq.

West Valley Demonstration Project Act of 1980, Public Law 96-368, 94 Stat. 1347, 42 USC 2021a et seq.

WSRC-OS-94-42, 1993, Federal Facility Agreement for the Savannah River Site, Administrative Document Number 89-05-FF, U.S. Department of Energy and South Carolina Department of Health and Environmental Control, Aiken, South Carolina. 


\subsection{BIBLIOGRAPHY}

DOE/ID-XXXXX, 2001, Tier I Closure Plan for the Idaho Nuclear Engineering and Technology Center Tank Farm Facility at the INEEL, Rev. 0 Draft, U.S. Department of Energy, Idaho Operations Office, Idaho Falls, Idaho.

DOE/ID-10802, 2001, Idaho Hazardous Waste Management Act/Resource Conservation and Recovery Act Closure Plan for Idaho Nuclear Technology and Engineering Center Tanks WM-182 and WM-183, Rev. 1, U.S. Department of Energy, Idaho Operations Office, Idaho Falls, Idaho.

DOE/ORP-2001-18, 2001, Single-Shell Tank Closure Plan, Appendix F, “Complex-Wide Closure Progress and Issues," Rev. 0 Draft, U.S. Department of Energy, Office of River Protection, Richland, Washington.

INEEL/EXT-99-01066, 2000, Idaho Nuclear Technology and Engineering Center Tank Farm Facility Conceptual DOE and HWMA/RCRA Closure Approach (FINAL), Idaho National Engineering and Environmental Laboratory, Idaho Falls, Idaho.

INEEL/EXT-2001-XX, 2000, Performance Assessment for the Tank Farm Facility at the Idaho National Engineering and Environmental Laboratory, Draft, Idaho National Engineering and Environmental Laboratory, Idaho Falls, Idaho. 